\title{
Design and development of a low-cost system to convert solar thermal energy into electricity for households in South Africa using solar concentrators
}

\author{
Lukas W. Snyman ${ }^{1 *}$ (D), Glen Maeko ${ }^{2}$ \\ 1. Institute for Nanotechnology and Water Sustainability, College for Science Engineering and Technology, \\ University of South Africa, Johannesburg, South Africa \\ 2. Department of Electrical Engineering, Tshwane University of Technology, Pretoria, South Africa
}

\begin{abstract}
South Africa is, due its specific latitude location in the southern hemisphere, exposed to high solar irradiation levels. Black thermal absorbers have a high absorbance for solar incident radiation, while commercial photovoltaic technology only converts about $10 \%$ of energy available in the solar spectrum. In this article, low-cost Peltier conversion cells, that are normally used for cooling purposes, and that are freely available in supply stores in South Africa, were identified as suitable conversion cells for converting thermal energy into electricity. Two prototypes of thermal-to-electricity energy conversion systems were subsequently designed and developed. Particularly, advanced pulse mode DC- to- DC conversion technology, a special electronic control system, was developed, that could extract high amounts of electrical energy from the cells and could store the energy in standard storage batteries. A 3 W and a 30 W output continuous conversion capacity system were developed. A power conversion of up to 2 W capacity per individual cell was achieved. The systems used no movable parts, and the lifespan of the systems is projected to be at least twenty years. Cost and viability analyses of the systems were performed and the results were compared to existing solar photovoltaic energy conversion systems. Combining the $30 \mathrm{~W}$ capacity system with a black body and reflector plate absorber system revealed a cost structure of only ZAR 0.8 per $k W h$, as compared with a derived ZAR 3 per $k$ Wh for a combined photovoltaic and solar geyser combination, as calculated for a ten-year term. The technology as developed is suitable to be incorporated in South African households and rural Africa applications.
\end{abstract}

Keywords: thermal energy, solar energy, photovoltaic technology, electronic control systems

Highlights:

- Extremely cost-effective harvesting and storage of solar energy in household context.

- Development of novel low-cost thermal energy to electricity conversion systems.

- Conversion to electricity at ZAR 0.80 per kWh.

- Household applications and labour-intensive job creation possibilities.

- Business creation possibilities under established intellectual property.

\begin{tabular}{|c|}
\hline Journal of Energy in Southern Africa 32(4): 102-116 \\
\hline DOI: https://dx.doi.org/10.17159/2413-3051/2021/v32i4a10661 \\
\hline Published by the University of Cape Town ISSN: 2413-3051 https://journals.assaf.org.za/jesa \\
\hline This work is licensed under a Creative Commons Attribution-ShareAlike 4.0 International Licence \\
\hline Sponsored by the Department of Science and Innovation \\
\hline
\end{tabular}

\footnotetext{
*Corresponding author: Email: snymalw@unisa.ac.za
} 


\section{Introduction}

Eskom grid electricity can currently be purchased by South African households at approximately ZAR 2.20 per kWhr (tax included) (e-Tshwane, 2020). A sliding scale up to about ZAR 5 per kWh is currently implemented for households using more than 1000 kWh per month. Lately, such supplies have become intermittent and unreliable in South Africa, due to high demand from a large low-income population, and a dependency on an aging and primarily coaland fire-steam-based technologies.

Solar photovoltaic (PV) systems are currently in popular demand for installation in South Africa households and business premises. However, capital outlay, installation and maintenance costs are high (Zwile-Gampio Snyman, 2018). Furthermore, commercially available PV cells are, on average, only $10 \%$ efficient and require high capital outlays.

Thermal energy is abundantly available in South Africa and Africa. This article reports on the development of prototype thermal energy- to- electricity conversion systems that are suitable for the South Africa household context. Particularly, an effective electronics charge extraction and electronics control module technology has been developed that enhances the efficiency of the systems. The reported results were achieved at the University of South Africa College of Science Engineering and Technology Campus in Johannesburg as well as previously at the Tshwane University of Technology. Conversion efficiencies and power-cost factors that were achieved are also given. The viability of applying this technology in the South African and African contexts is analysed.

\section{Viability of thermal energy to electricity conversion systems in South Africa}

Figure 1 shows the long-term average solar irradiation values as recorded for South Africa in term of $\mathrm{kWh} / \mathrm{m}^{2}$. South Africa has the second-highest solar irradiation in the world, after Arizona in the USA, with an average of $20 \mathrm{MJ} / \mathrm{m}^{2}$ per year or $6.5 \mathrm{kWhr}$ per day (Solargis, 2019; Zse, 2021).

Figure 2 shows spectral energy density in terms of $\mathrm{W} / \mathrm{m}^{2} / \mathrm{nm}$ wavelength of incident solar radiation (Cleveland and Morris, 2017). The space irradiation levels, as well as the irradiation that reaches the surface of the earth, are shown. Radiation energy of, on average, $0.25 \mathrm{~W} / \mathrm{m}^{2} / \mathrm{nm}$ wavelength is shown for the ultraviolet region, $1.25 \mathrm{~W} / \mathrm{m}^{2} / \mathrm{nm}$ wavelength for the visible, and $0.50 \mathrm{~W} / \mathrm{m}^{2} / \mathrm{nm}$ wavelength for the infrared region. If the spectral density is multiplied with the total bandwidth of irradiation, we derive, respectively, $3.75 \mathrm{~W} / \mathrm{m}^{2}$ for the ultraviolet radiation, $250 \mathrm{~W} / \mathrm{m}^{2}$ for the visible region, and $500 \mathrm{~W} / \mathrm{m}^{2}$ for the infrared wavelength region. The infrared long-wavelength region hosts about twice as much energy as the visible region, and about 100 times as much as the ultraviolet region.

Using the above statistics, and using a $10 \%$ conversion efficiency as achieved on average for com-

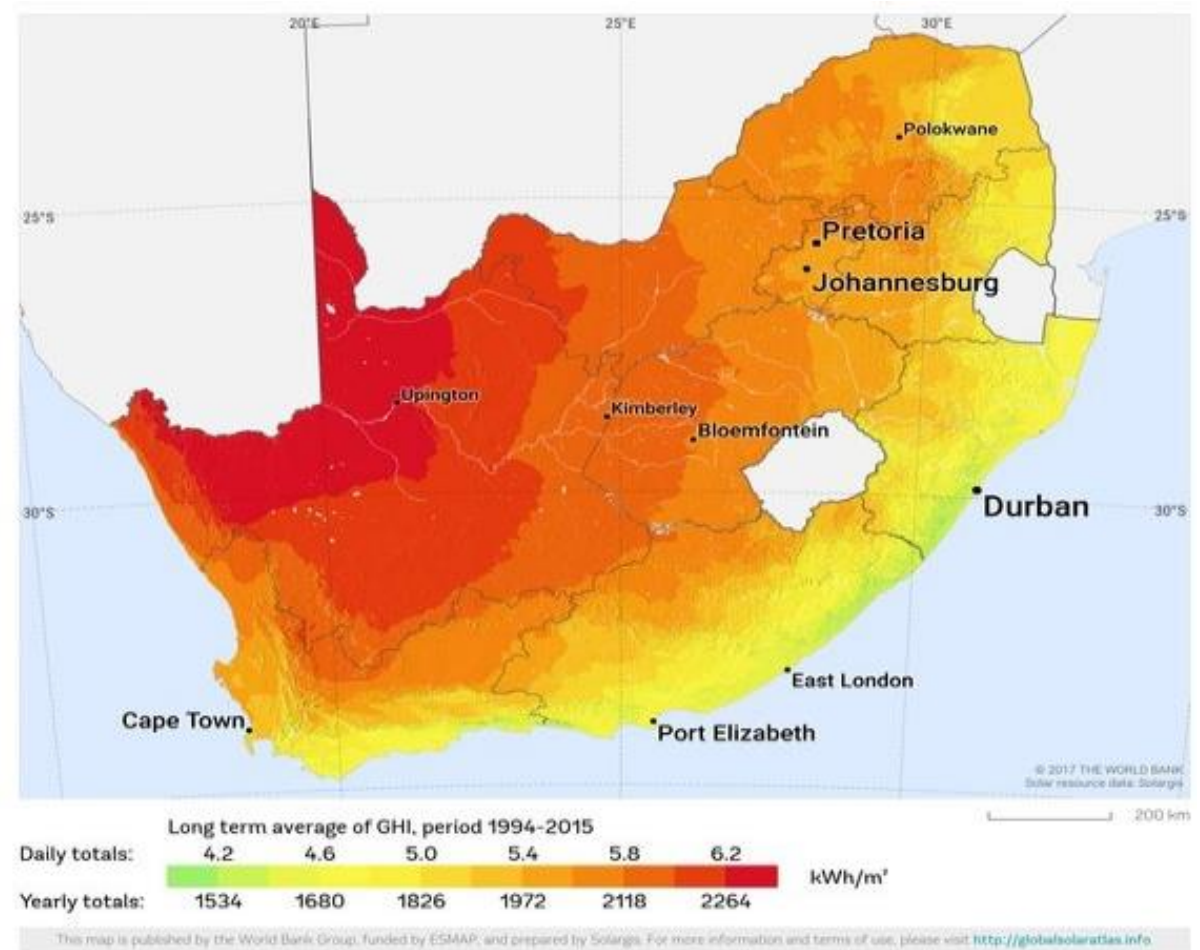

Figure 1: Average solar irradiation levels for South Africa, 1994-2015 (Solargis, 2019). 


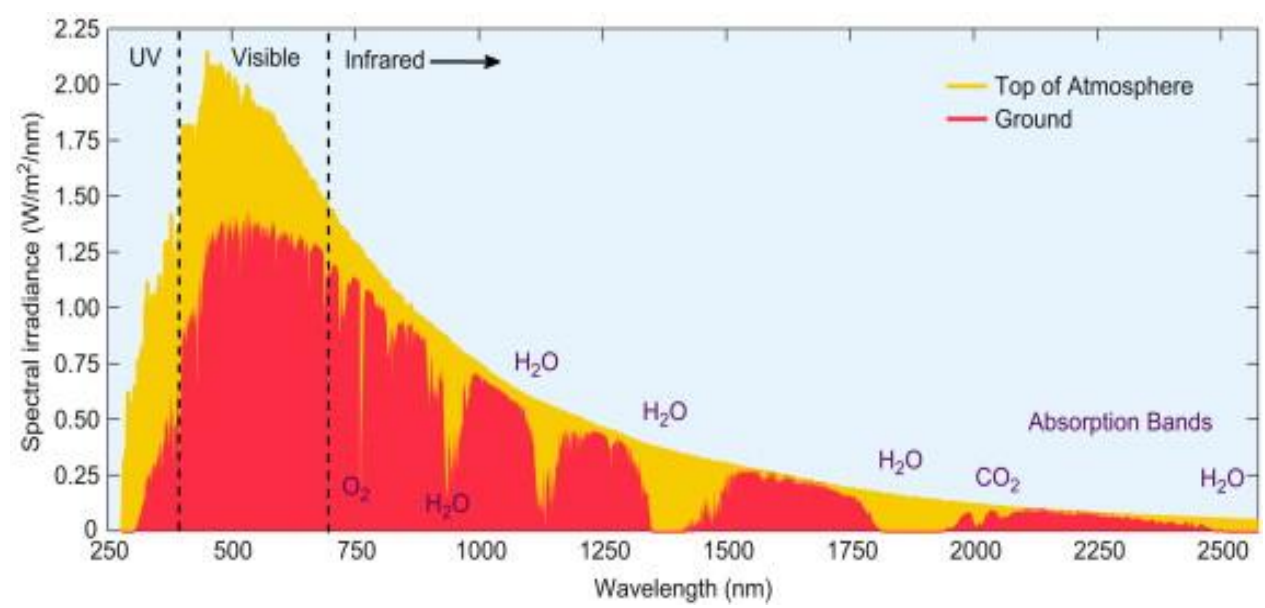

Figure 2: Solar radiation spectrum (Cleveland and Morris, 2019).
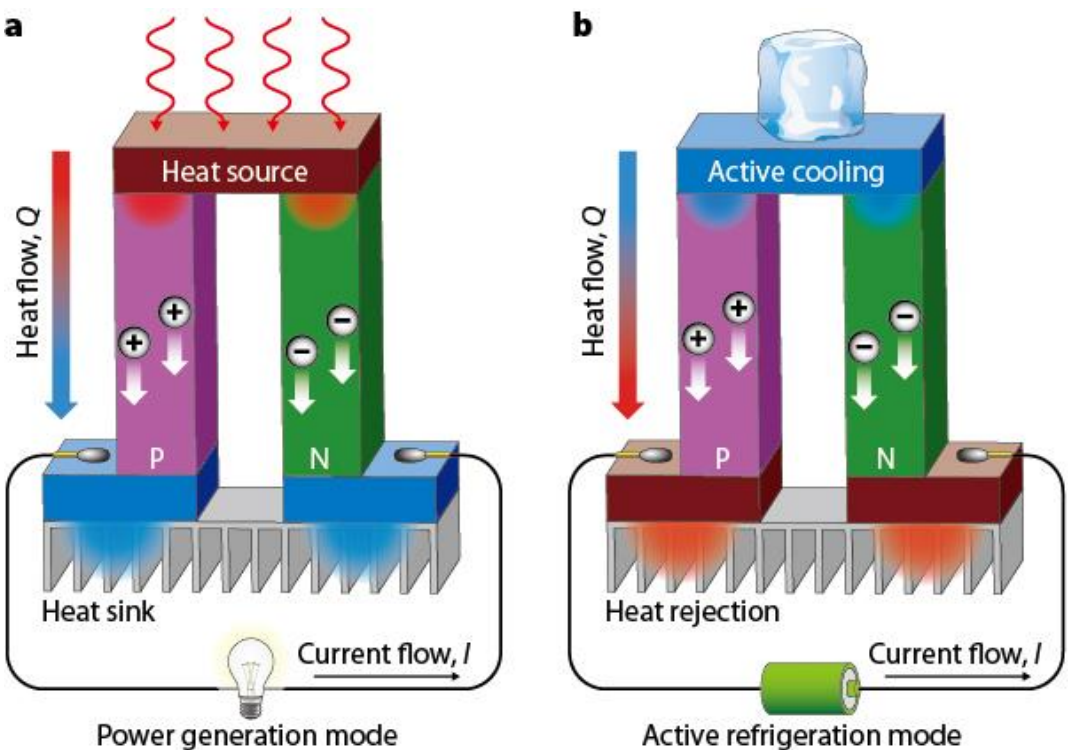

Figure 3: Refrigeration or power-generation modes (Snyder, 2008)

mercially available PV cells, and a potential $80 \%$ average absorption of thermal energy for black thermal absorbers, it is calculated that about 80 times more energy can be absorbed with thermal absorber systems per square metre than by PV cells. Using Gauteng as a reference area with an average of about $6.2 \mathrm{kWhr} / \mathrm{m}^{2}$ per day of usable thermal energy (as per Figure 1) and a $3 \times 3.5 \mathrm{~m}$ or $10 \mathrm{~m}^{2}$ collection area system on a house rooftop, up to 50 kWh of energy per day, or about $1500 \mathrm{kWh}$ per month, could be collected.

In this way, a household could be supplied with all the hot water needed for personal and domestic purposes. If a further portion of the collected thermal energy could be converted to electricity, the majority of electrical appliances in the household could also be served with this energy. Poor urban and rural houses obviously use less electrical energy, and they could even operate these systems on a completely self-sustainable basis.

\section{Thermal energy-to-electricity conversion cells available on the international market}

Peltier thermoelectric cells are used in cooling boxes to convert electrical energy into thermal energy. Thermal energy-to-electricity (TE) cells are essentially particle heat engines where the working fluid is electrons and hole charge carriers. The 'thermopower' of a material depends on the material's elemental and crystal structure. Figure 3 illustrates the operation of a thermoelectric cell in both the active power generation mode and also in the refrigeration mode (Snyder, 2008). Figure 4 illustrates the construction of a commercially available thermoelectric cell. The single-stage thermoelectric module is typically composed of TE elements (nand p- types) that are connected electrically in series and thermally in parallel, and sandwiched between two ceramic plates. The TE elements are interconnected with electric conductors (such as copper) using a complex system of copper plate 
metallisation. The ceramic plates form the cold and hot surfaces of the module and also provide mechanical integrity to the structure. Ceramic plates are commonly used for end- and mounting-plates, since ceramic is one of the best materials to provide high electrical isolation while providing low thermal resistance.

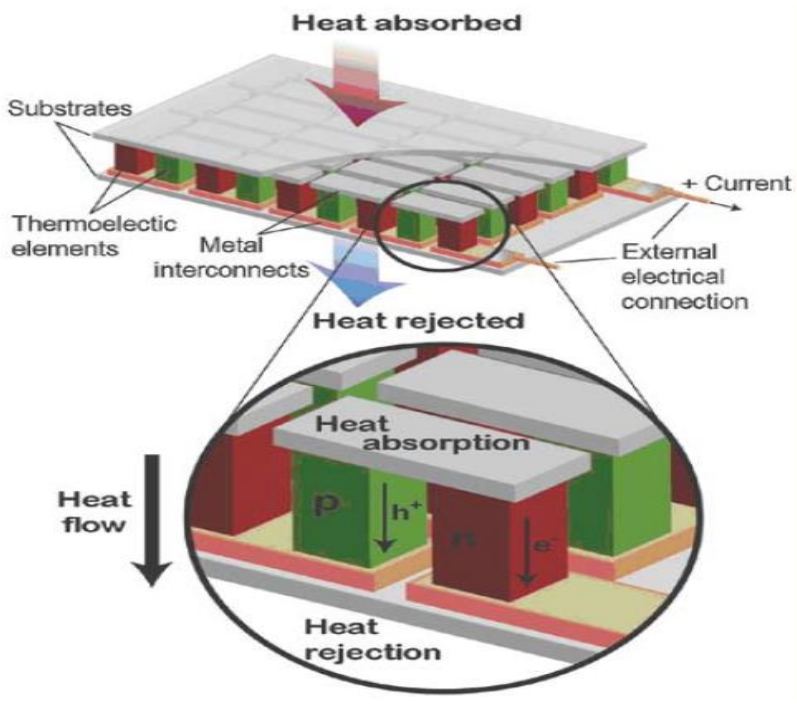

Figure 4: A thermoelectric module used for Peltier based cooling purposes (Snyder, 2008)

Typically, metals have small thermopower because most metals have half-filled bands. Electrons (negative charges) and holes (positive charges) both contribute to the induced thermoelectric voltage, thus cancelling each other's contribution to cooling.

Semiconductors, however, can be doped with an excess number of electrons or holes, and hence can generate large thermopower, depending on the charge of the excess carriers (CRC Handbook, 1995). The outstanding challenge in the study of thermo-electrics is to find materials that can provide power conversion and refrigeration at high efficiency. The thermoelectric power, $\mathrm{S}$, is defined as the thermoelectric voltage, $\mathrm{V}$, produced per degree temperature difference, as in Equation 1.

$$
S=\frac{\Delta V}{\Delta T}
$$

Since charge carriers must move through the material, the material should conduct electricity well, or the deleterious effect of resistive heating and energy losses will be enhanced. The material should also act as a thermal insulator, so a good thermal conductor will rapidly dissipate the temperature difference established.

The best thermo-electric materials (Boukai, 2008) involve a trade-off among the three factors, combining a high thermopower and electrical conductivity, but with low thermal conductivity. The thermopower is sensitive to the density of states and phonon-electron scattering, which may be very different in certain materials at the nanoscale. The efficiency of thermoelectric material is determined by the dimensionless figure of merit, ZT, in Equation 2.

$$
Z T=\frac{S^{2} \sigma}{\kappa} T
$$

Where $\sigma$ is the electrical conductivity, $\kappa$ is the thermal conductivity consisting of both photon and electronic contributions, and $\mathrm{T}$ is the temperature. Efficient devices in this regard, require substantial 'materials and engineering'.

Table 1 illustrates materials conversion efficiency for thermoelectric powers for a range of devices that have been developed through recent research and development actions, for different temperature ranges, and a different combination of thermoelectric materials used as $\mathrm{p}$ and $\mathrm{n}$ legs. The conversion efficiency of these materials increases as the temperature difference increases.

A group at Massachusetts Institute of Technology revealed that they have developed devices with a very high conversion efficiency, up to $80 \%$, by using nanotechnology engineering technology and by using mesh structures of atoms, whereby the charge transfer in the mesh could be enhanced, but phonon transfer be retarded (Chen and Hayward, 2008). Currently, the cost of cells as available on the market of the type as listed in Table 1 are still extremely high (Boukai, 2008) - a minimum of ZAR 1500 per $10 \mathrm{~W}$ cell, according to a survey conducted for this research. Unfortunately, at this stage, all these technologies have all to be imported. However, South Africa and Africa have ample raw materials with which to develop selected sections of these technologies on a value-added basis.

\section{Experimental procedures 4.1 Design and construction}

As a first test analysis, we designed a small laboratory protype TE conversion system in order to test the performance of commercially thermoelectric conversion cells as available in South Africa and sold by a Chinese company (Thermodynamic Electronics Jiangxi Corp, 2020). An intriguing research question in this experiment was to determine if these units, that are normally used for cooling applications, could also be used to convert thermal energy to electrical power when heat was supplied to the one side of the module and the other side was subjected to a heat sink, such as a large metal block or a water mass heat sink system. 
Table 1: Comparison of the figure of merit (ZT factor), and the Seebeck coefficient (S) of available thermoelectric materials (Boukai, 2008).

\begin{tabular}{|c|c|c|c|c|}
\hline $\begin{array}{l}\text { Thermoelectric material } \\
\text { (With } p \text { and } n \text { legs) }\end{array}$ & $Z T_{\text {avg }}$ & $\begin{array}{c}S \\
\text { (Device tem- } \\
\text { perature } \\
25-25^{\circ} \mathrm{C} \text { ) }\end{array}$ & $\begin{array}{c}S \\
\text { (Device tem- } \\
\text { perature } \\
100-400{ }^{\circ} \mathrm{C} \text { ) }\end{array}$ & $\begin{array}{c}S \\
\text { (Device tem- } \\
\text { perature: } \\
400^{\circ} \mathrm{C} \text { ) }\end{array}$ \\
\hline $\mathrm{p} / \mathrm{n}-\mathrm{Bi} 2 \mathrm{Te} 3$ & 0.81 & 7.8 & & \\
\hline $\mathrm{p}-\mathrm{ZnSb} 3+\mathrm{n}-\mathrm{Bi} 2 \mathrm{Te} 3$ & 0.67 & 6.8 & & \\
\hline p- Zn4-xCdxSb3 + n-Bi2Te3 & 0.84 & 8 & & \\
\hline $\mathrm{p} / \mathrm{n}-\mathrm{PbTe}$ & 0.56 & & 6.2 & \\
\hline p-Zn4Sb3 + n-PbTe & 0.77 & & 7.8 & \\
\hline p-Zn4-xCdxSb3 + n-PbTe & 0.97 & & 9.2 & \\
\hline p-Zn4-xCdxSb3 + "n-Zn4Sb3" & 1.37 & & 11.5 & \\
\hline $\mathrm{p} / \mathrm{n}-\mathrm{PbTe}+\mathrm{p} / \mathrm{n}-\mathrm{Bi} 2 \mathrm{Te} 3$ & 0.74 & & & 10 \\
\hline p-Zn4Sb3/n-PbTe + p/n- Bi2Te3 & 0.87 & & & 11.3 \\
\hline $\begin{array}{l}\text { p-Zn4-xCdxSb3/n-PbTe + p/n- } \\
\text { Bi2Te3 }\end{array}$ & 1.02 & & & 12.6 \\
\hline p/"n"-Zn4-xCdxSb3 + p/n-Bi2Te3 & 1.28 & & & 14.6 \\
\hline Nano-structured p/n -Bi2Te3 & & 20 & & \\
\hline
\end{tabular}

The specifications of the thermoelectric cooling module as per the operator's manual are as follows (Communica SA Pty Ltd, 2019):

Part number: TEC1-12706

Refrigeration Mode

Size: $40 \mathrm{~mm} \times 40 \mathrm{~mm}$

Supply voltage: $12-14.5 \mathrm{~V}$

Max Current: 6A

$Q_{\text {max: }} 68.8 \mathrm{~W}$

TE material: $\mathrm{n}$ and $\mathrm{p}$-type legged silicon

Thermoelectric power, ZT: 0.01 - 0.6

Price: Communica in South Africa: ZAR 113 per module (From Thermodynamic Electronics, China: USD 3.5 per cell)

Figure 5 shows a schematic presentation of the first design for constructing a small-scale TE energy convertor. This system used only two TEC1-12706 thermoelectric cell modules and were coupled to a heating element on the one side and a cooling water bath on the other. The purpose of this prototype was to test the basic efficiency that could be achieved when converting thermal energy to electricity per individual module. We used elements of a standard spiral stove plate to heat the aluminum block to supply heat energy to the hot side of TE modules. A heat sink was mounted on the other side of the TE modules, and this was placed inside the water bath for effective heat flow through the cells into the water bath. The temperature of the water was controlled by blowing air at room temperature of about $20^{\circ} \mathrm{C}$ over the bath.

Two methods of impedance matching were investigated, as illustrated in Figure 6: (1) a seriesparallel hook-up of modules in which DC resistance matches the DC resistance of a load cell, and (2) using a common DC-to-DC conversion circuit to step up the voltage and current from the output of the modules to the battery load cell. 


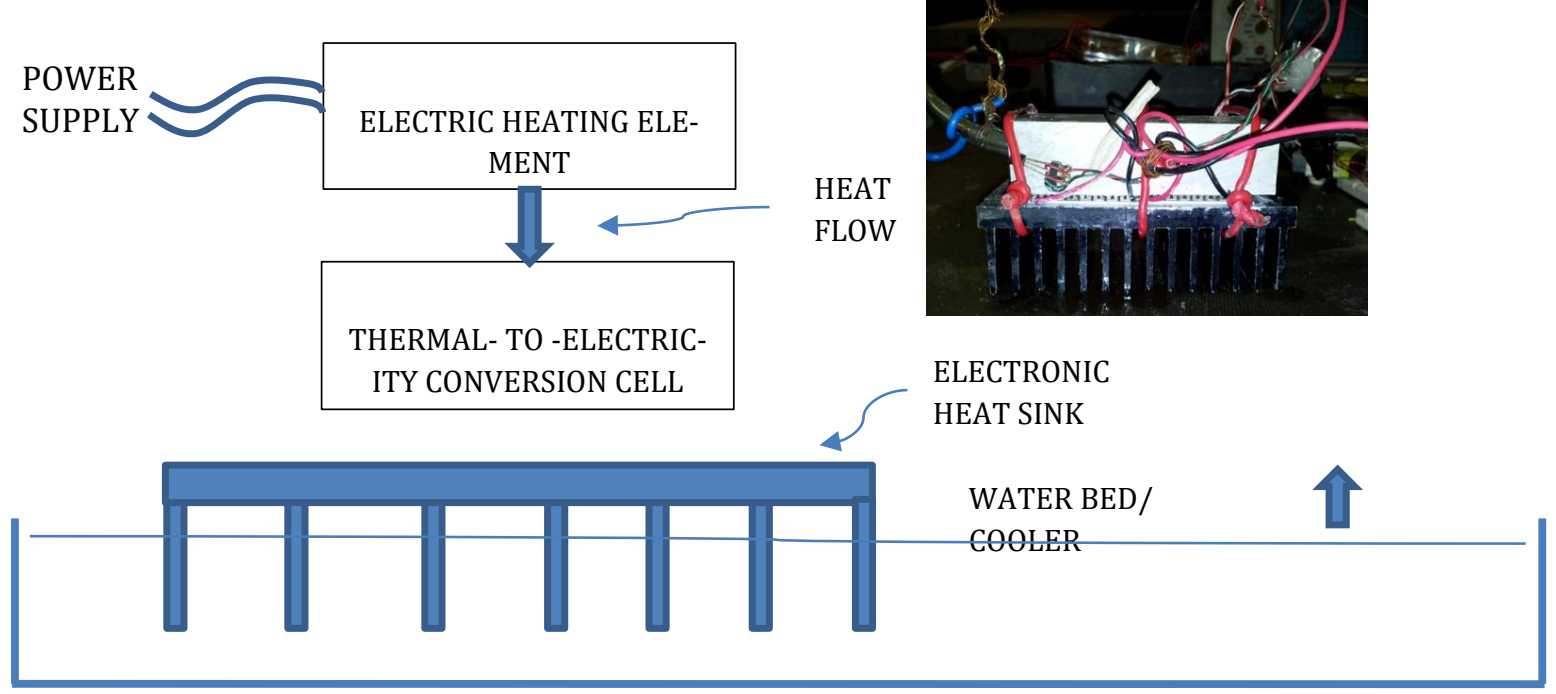

Figure 5: Schematic presentation of the basic experimental test set up used to test the achievable power transfer from thermal-to-electricity conversion cells.

a)

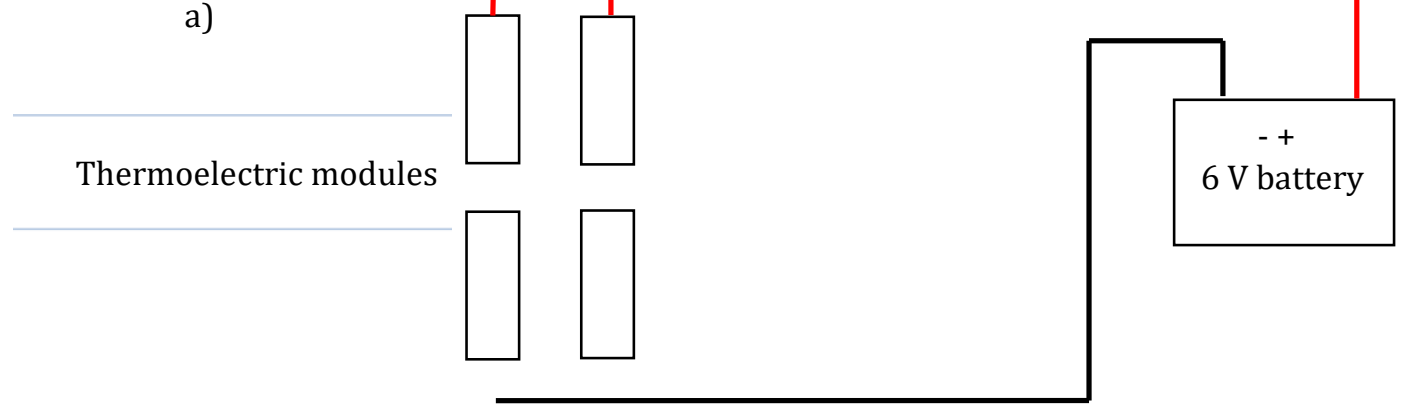

Thermoelectric modules

b)

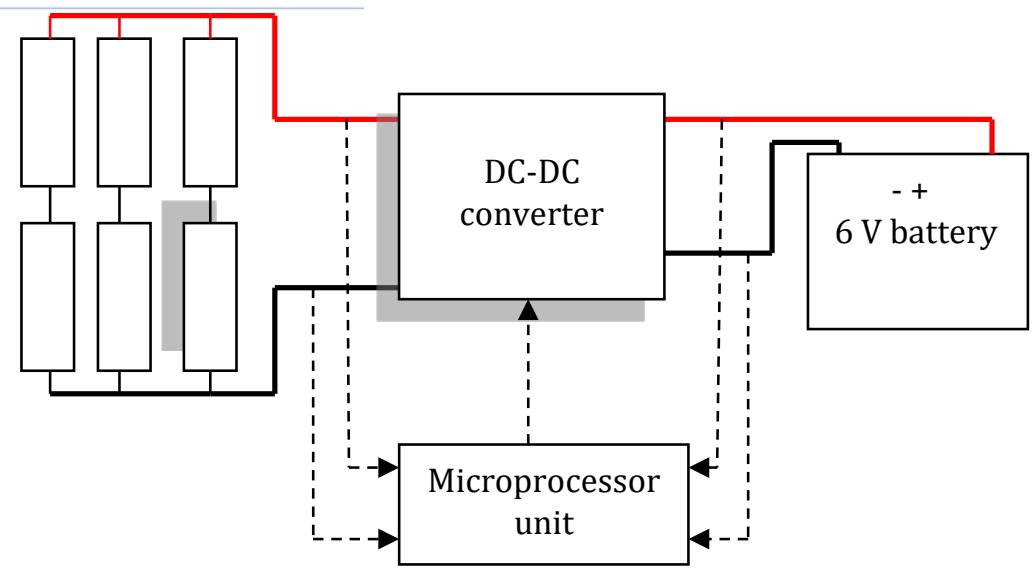

Figure 6: Schematic presentaton of our designs to ensure a maximum power transfer from the TE modules to the battery load cell. 


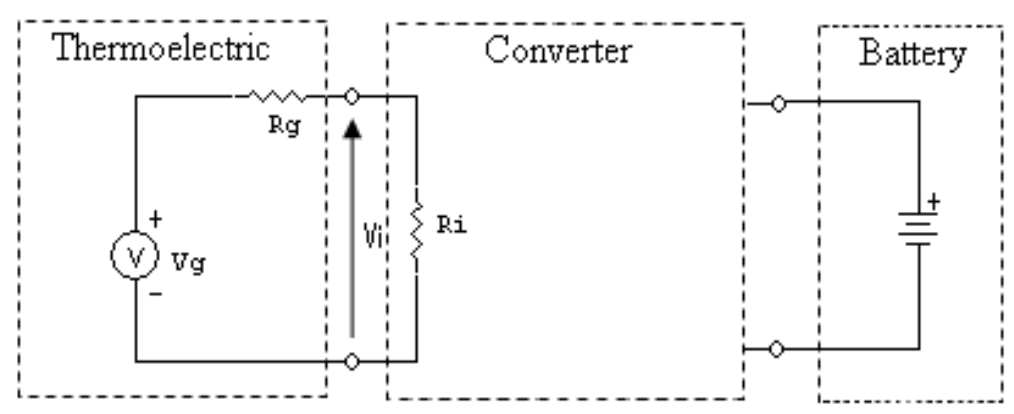

Figure 7: Maximum power transfer considerations.

The open-circuit voltage output of a TE converter was applied to a series circuit consisting of the module's internal resistance $\left(\mathrm{R}_{\mathrm{g}}\right)$ and the $\mathrm{DC}-\mathrm{DC}$ converter input resistance $\left(\mathrm{R}_{\mathrm{i}}\right)$, as in Figure 7 .

As in any series circuit, the voltages will 'drop' in proportion to the resistances. Thus, if the no-load voltage was $3 \mathrm{VDC}$, the $\operatorname{Rg}$ was $3 \Omega$, and Ri was $6 \Omega$, there would be a 2 VDC drop across the Ri, according to Equation 3.

$$
V_{\text {Load }}=\left(V_{N L}\right)\left(\frac{R_{i}}{R_{g}+R_{i}}\right)
$$

The formulae in Equations 4-7 could be used to determine load voltage, current, and power for various load resistances in each case.

$$
\begin{aligned}
& V_{L}=V_{N L}\left(\frac{R_{i}}{R_{g}+R_{i}}\right) \\
& I_{L}=\frac{V_{i}}{R_{i}}
\end{aligned}
$$

and the power delivered to the load was then:

$$
P_{L}=V_{L} \times I_{L}
$$

The open and short circuit tests were conducted to calculate the cell's internal resistance and the maximum possible output power. $\mathrm{I}_{\mathrm{sc}}$ was obtained by simply closing the switch and $V($ oc) when the switch was open:

$$
\begin{aligned}
& R(\text { internal })=\frac{V(o c)}{I(s c)} \\
& P(\text { load } . \max )=\frac{V o c * I s c}{4}
\end{aligned}
$$

In the larger designs, involving more than one cell, a circuit configuration as in Figure 6 (b) was used and a DC-to- DC step-up converter was developed in order to connect the outputs of the thermoelectric cells to deliver an output open voltage of approximately $6.5 \mathrm{~V}$, such that a small $6.5 \mathrm{~V} 10 \mathrm{Ah} \mathrm{r}$ lead-acid battery could be charged. Two step-up DC-DC converter circuits were designed, with the microprocessor providing a 180-degree phase difference to ensure adequate transfer of collected charge during each respective 180-degree cycle to compensate for the normal $50 \%$ duty cycle as normally assumed with a DC-to-DC induction coilbased converters. For the microprocessor to control the duty cycle, and exact step-up voltage required for charging the battery, it was necessary to obtain voltage samples from the TE converter and battery. This was done through appropriate voltage sensing technology in a series resistance network. The PIC16F877 micro-processor from Microchip was chosen to accomplish the time cycling and control sections of the circuitry. It was selected because of its ability to monitor multiple signals and convert them to digital, as well as its ability to output a PWM signal with a variable duty cycle. It had 40 pins, five I/O ports, eight input channels, two PWM modules, and a ten-bit analogue-to-digital converter. The system further included two temperature sensors of the type LM35. The analogue output of the two sensors was fed to the microcontroller PIC16f877A, which converted them to digital values using the internal analogue-to-digital converter and display the values on the LCD $16 * 2 \mathrm{MC} 1602 \mathrm{C}$-Syl. The analogue output of the current and voltage sensors was also fed to the microcontroller. The output current was designed to accommodate a maximum of $500 \mathrm{~mA}$ charging current. The micro-processor generated a $10 \mathrm{Khz}$ frequency at a duty cycle of $50 \%$ which is used for pulsing the MOSFET drivers. Figure 8 shows a photograph of the component pacing and packaging into a suitable box housing. It shows the developed DC to DC conversion system that was developed. The primary purpose of this unit was, firstly, to extract as much as possible of the charge carriers that was separated in the thermionic cells (as in Figure 3), and, secondly, to suitably up-convert the output voltage so that the charges could effectively be transferred to a storage battery. The system was designed using the researchers' own understanding of electronics theory and circuitry, and was disclosed as a preliminary RSA Patent 3071 and 3072 in 2009 and a SA Patent 05297 in 2016. 


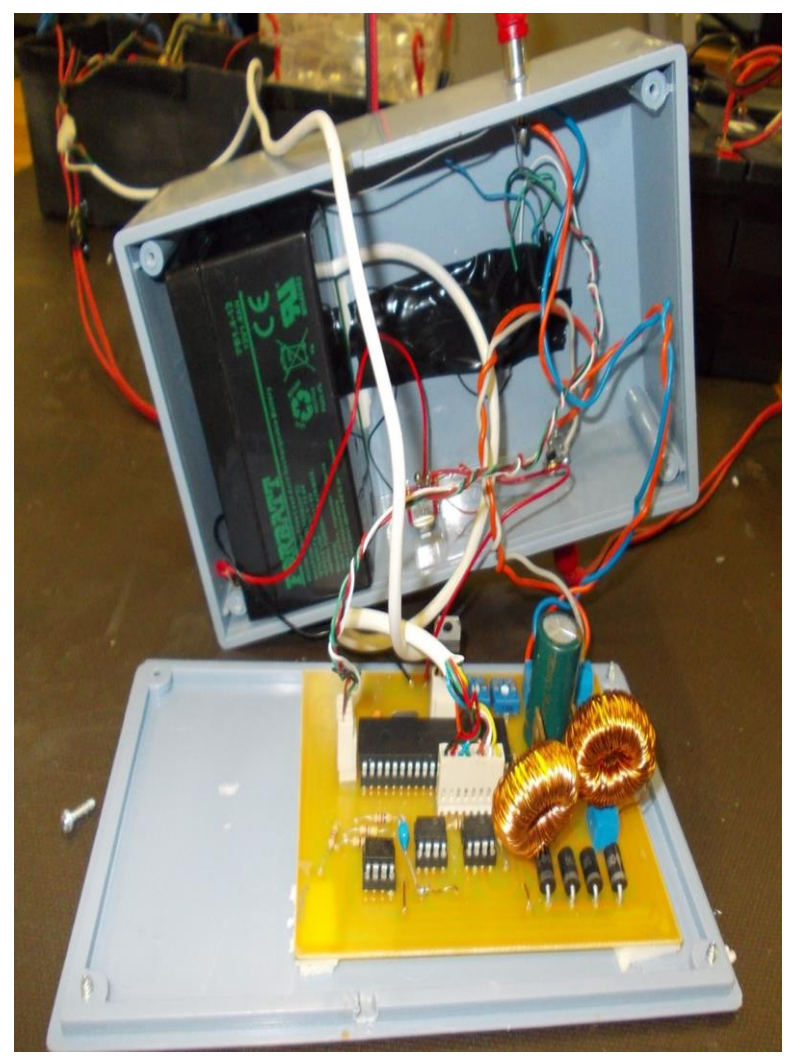

Figure 8: The component placing and packaging of TE optimiser into a suitable box housing.

\subsection{Development of a larger 30-Watt TE continuous conversion system}

The above concepts and technology were subsequently applied to the construction of a larger $30 \mathrm{~W}$ TE conversion system. Figure 9 shows the developed system at the UNISA Johannesburg Florida laboratories. Notably, a low-cost large-area reflective plate thermal energy absorber was developed and black poly-ethelyne piping was used as the primary solar irradiation absorber element, while the reflective back plating provided additional radiation to the piping. Water was used as the primary energy transfer medium between the absorber and the geyser. A conventional 200 litre solar geyser was added to the system, and storage of about $10 \mathrm{kWh}$ per day (in winter) in the Johannesburg area has been confirmed. The total capital outlay of such a system was approximately ZAR 8000 ZAR (Twite et al, 2018) - approximately one third of the cost of a standard integrated solar water-heating system commercially available in South Africa (One Energy Company, 2018).

A large block, $30 \times 30 \mathrm{~cm}$, served as mounting block arrays for the TE cells, which were pasted to the block with high-quality thermal paste. Two arrays consisting of 14 cells each were constructed, each consisting of two series combination configurations of seven each. Each block array was covered with a standard large area and finned aluminium heat sink, obtained from a local electronic supplier.

A larger DC-to-DC converter, operating on similar principles to those outlined in Section 4.1, was coupled to the system. The entire prototype system was built using local materials that were commercially available at supply stores in South Africa.

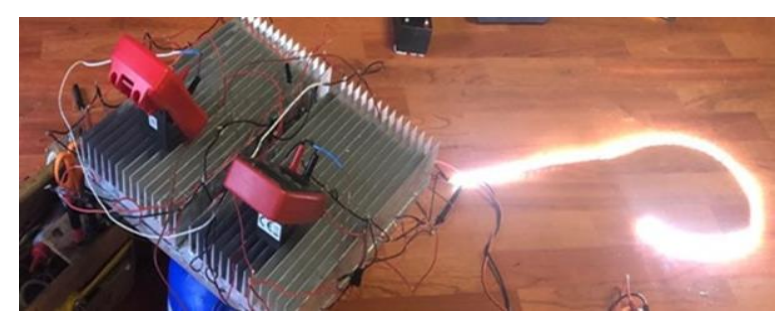

(a)

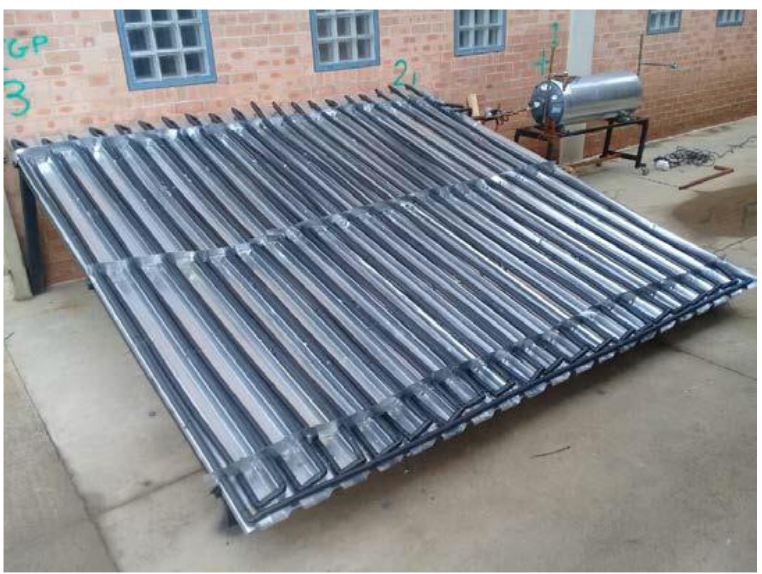

(b)

Figure 9: (a) The low-cost large-area heatabsorbing system developed at the Unisa Research Development Laboratories. The design incorporates suspended black piping on reflective galvanised sheeting to increase the absorption of heat in the pipes from refection of solar irradiation from below. (b) The larger thermo- electric converter system in operation, supplying energy to string of LED electric lamps.

\section{Results and discussion}

\section{1 Measurement of output characteristics of} one TE cell

Table 2 shows the measurements that were obtained for a single cell as well as the dynamic variation of the internal resistance with an increase in temperature gradient across the ceramic plates of the cell. Figure 10 shows power transfer plots for one TE cell to a fixed resistive load of $20 \Omega$ and a delta $\mathrm{T}$ of $80^{\circ} \mathrm{C}$ across the sides of the cell. Fig 11 shows the derived internal resistance for one cell as a function of temperature on the hot side of the cell. The value of the internal resistance is an important figure of the merit of TE cells, as it indicates the maximum current that may be supplied by the cell. 
The results were obtained by varying the load resistance from $0.5-4 \Omega$ and then noting the power delivered from the source for each load resistance. Since the total internal series resistance limits the maximum power transfer from a source to a load with direct coupling, a DC-to-DC converter between the TE module and the battery load was used.

\section{2 Measuring the power transfer character- istics of the developed TE conversion systems}

Since a battery normally contains high series resistance when discharged, we subsequently tested the power transfer into a fixed $20 \Omega$ load for both direct coupling and using the DC-to-DC converter. Figure 10 shows the total power transfer that was calculated and Figure 11 shows the internal resistance that was derived for the cells as a function of temperature.

Interestingly, the DC-to-DC converter as developed in Section 4 provided a better transfer, about $15 \%$, than direct coupling to the load. This behaviour is attributed to input impedance matching conditions of the DC-to-DC converter at high frequencies providing a better effective impedance match to the cell and ensuring more current to be transferred into the inductor with each cycle, and that to be transferred to a higher V-I ratio at the output of the DC-to-DC converter.

Subsequently, the two cell TE module were coupled via the DC-to-DC converter to the $6 \mathrm{~V} 10$ Ahr battery. From Figure 12, it is seen that the TE converter draws electrical power (about $6 \mathrm{~W}$ ) from the battery when the temperature difference is below $10{ }^{\circ} \mathrm{C}$ and the output voltage from the TE modules is not enough to produce output voltage greater than the voltage of the battery. The figure also shows the output power of the DC-to-DC converter delivered to the battery of $2.67 \mathrm{~W}$. This value is reasonably close to the maximum of $3.2 \mathrm{~W}$ as predicted by the results in Table 2 for two modules (1.6 $\mathrm{W}$ derived for one module in Section 5.1).

It was hence derived that the TE DC-to-DC coupler controller configuration provided about $26 \%$ better charge transfer than the direct coupling method. The DC-to-DC controller configuration also avoided a back drain of the battery (caused by the low internal resistance of the cells when they are cold and do not provide enough voltage output).

Table 2: Open and short circuit testing results for one Peltier TEC1-12706 module as a function of temperature (using water at $20^{\circ} \mathrm{C}$ as a cooling medium)

\begin{tabular}{cccccc}
\hline Time $(s)$ & $\begin{array}{c}\text { Temperature at } \\
\text { heat source side } \\
\left({ }^{\circ} \mathrm{C}\right)\end{array}$ & Voc $(V)$ & Isc $(A)$ & $\begin{array}{c}\text { Pload-max } \\
(W)\end{array}$ & R internal ( $\Omega)$ \\
\hline 0 & 110 & 4.37 & 1.44 & 1.57 & 3.02 \\
40 & 105 & 4.2 & 1.36 & 1.42 & 3.09 \\
63 & 100 & 3.79 & 1.26 & 1.19 & 3.01 \\
80 & 95 & 3.6 & 1.22 & 1.10 & 2.95 \\
98 & 90 & 3.41 & 1.16 & 0.99 & 2.94 \\
120 & 85 & 3.17 & 1.09 & 0.86 & 2.91 \\
151 & 80 & 2.9 & 1 & 0.72 & 2.9 \\
179 & 75 & 2.6 & 0.94 & 0.61 & 2.86 \\
212 & 70 & 2.4 & 0.84 & 0.50 & 2.83 \\
245 & 65 & 2.13 & 0.76 & 0.40 & 2.8 \\
283 & 60 & 1.9 & 0.68 & 0.32 & 2.79 \\
323 & 55 & 1.65 & 0.61 & 0.25 & 2.71 \\
375 & 50 & 1.39 & 0.52 & 0.18 & 2.67 \\
435 & 45 & 1.14 & 0.43 & 0.12 & 2.65 \\
511 & 40 & 0.89 & 0.33 & 0.08 & 2.54 \\
612 & 35 & 0.65 & 0.26 & 0.04 & 2.5 \\
720 & 30 & 0.43 & 0.18 & 0.02 & 2.44 \\
965 & 25 & 0.23 & 0.1 & 0.005 & 2.3 \\
\hline
\end{tabular}




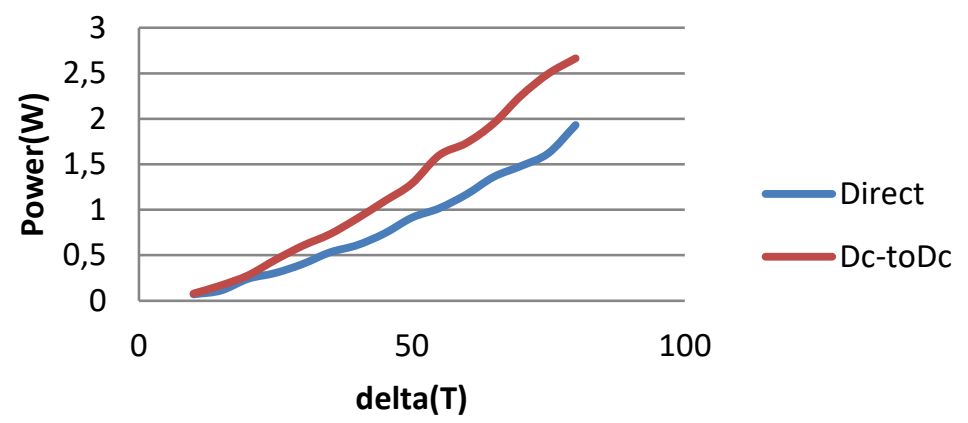

Figure 10: Power transfer plots for one TE cell to a fixed resistive load of $20 \Omega$.

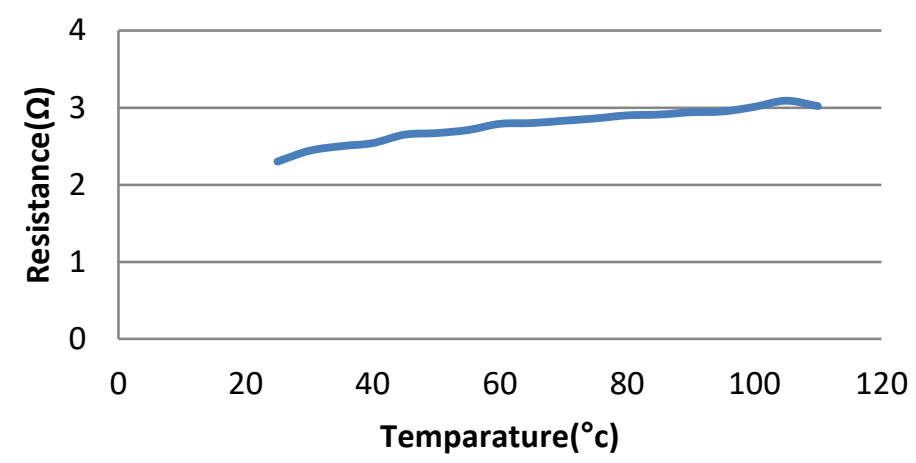

Figure 11: Internal resistance of one TE cell as a function of the temperature difference between the cell's plates.

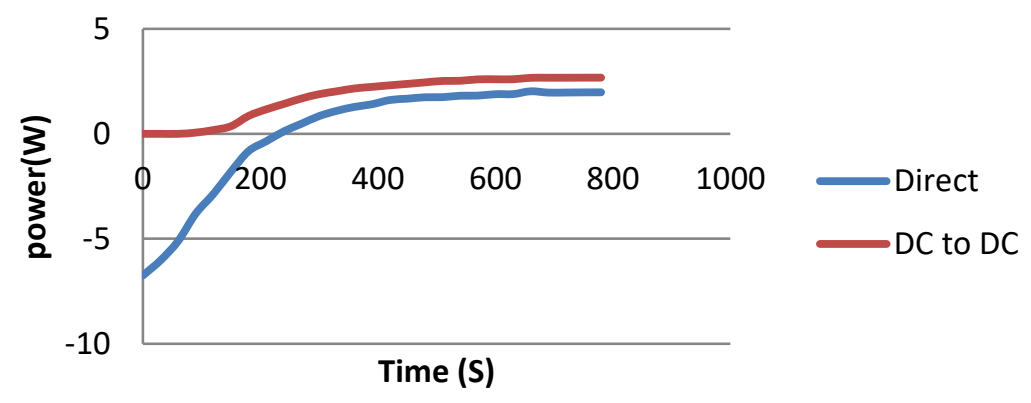

Figure 12: Power transfer plots for a TE conversion module containing one cell and coupled to $6 \mathrm{~V} 10 \mathrm{Ahr}$ lead-acid battery and for a delta $\mathrm{T}$ of $65^{\circ} \mathrm{C}$.

The measured output voltage for the larger system as described in Section 4.2 above was measured as $30 \mathrm{~V}$ and $30 \mathrm{~W}$ when the hot side of the converter was heated with hot water to $80{ }^{\circ} \mathrm{C}$, and with passive air cooling applied on the finned heat sinks. Comparing the number of cells of 14 per array as utilised in the larger design and the applied temperature difference, the output tested under controlled conditions correlates roughly with the statistics as derived for the single cell analyses of achieving about $2 \mathrm{~W}$ output per cell at $80{ }^{\circ} \mathrm{C}$ temperature difference. Higher losses of thermal energy, however, occurred on the larger system due to larger exposed areas of the heated side to ambient air in the geyser coupled configuration.

\subsection{Determining the efficiency of one cell in the 3 W TE conversion system}

To determine the efficiency of the cell, a block of aluminium was heated to $110^{\circ} \mathrm{C}$ and placed on the cell mounted on a heat sink placed in water. It was then allowed to cool without thermal heating to about $100^{\circ} \mathrm{C}$ for 63 seconds. Hence Equation 9.

$$
\begin{aligned}
& \Delta Q\left(110^{\circ} \mathrm{C} \text { t0 } 100^{\circ} \mathrm{C}\right)=m * \mathrm{cp} * \Delta \mathrm{T} \\
& =0.234 * 910 * 10 \\
& =2.1294 \mathrm{~kJ}
\end{aligned}
$$

The heat flow from the heater block through the TE cell was therefore as per Equation 10. 


$$
H=\frac{\Delta Q}{t}=\frac{2129.4}{63}=33.2 W
$$

This leads to a determination of the efficiency of one cell as in Equation 11.

$$
\eta=\frac{\text { Pelectrical }}{H} * 100=\frac{1.43}{33.2} * 100=4.31 \%
$$

Since thermal energy was also lost through parasitic conduction, parasitic convection through air and radiation, a determined thermal to the electrical conversion efficiency of approximately $5 \%$ can be assumed.

If the power transfer of power from the TE module to the battery could be further improved to about $3 \mathrm{~W}$, as in Table 2, and the parasitic losses further reduced, it is predicted that a power transfer efficiency of the order of $10 \%$ can be achieved.

\subsection{Predicted economics and cost savings as associated with utilisation of the larger TE conversion system}

Research shows that a medium-sized household in South Africa uses about 100-150 kWh of electricity per month, or 3-5 kWh per day), for household purposes excluding water-heating. Water heating consumes about 300-500 kWh per month, or 10-15 kWh per day.

The TE converter technology developed in this study allows for easy upscaling by incorporating more TE cells into the converter. TE cells of the type as investigated in this study can currently be bought on the Web from overseas suppliers for USD 3.5 (roughly ZAR 50) per cell (Thermonamic Electronics, 2019). If the system is expanded to use 100 cells, coupled to a conventional domestic geyser hot water reservoir system, continuous power of $150 \mathrm{~W}$ (about $3 \mathrm{kWh}$ per day) could be generated.

If the TE conversion unit has about $2 \mathrm{kWh}$ capacity per day, this proportion of the available $10 \mathrm{kWh}$ per day as collected by the thermal absorber array as in Fig 9 (a) can be converted to electricity. An additional ZAR 10000 will be added to the capital outlay, and the running costs of such a system would amount to about ZAR 0.80 per $\mathrm{kW}$-hr. The lifetime of the TE systems developed in this study is estimated at 20 years, since no movable or seriously degrading materials are used. Peltier cells currently used for cooling purposes in cooler box applications have an exceptional reliability record, despite the temperature cycling they are often exposed to.

Figure 13 schematically compares this technology with existing PV technology. Current PV cells cost of about ZAR 10000 for a $200 \mathrm{~W}$ collection system - an average of USD 3 (ZAR 50 per W) (One Energy Company, 2018; Sustainable Co. ZA, 2019). The energy must be conditioned and regulated by a regulator to prevent overcharging or undercharging of batteries. Battery technology has become extremely sophisticated and, on average, according to usage patterns, needs to be replaced every two years. The lowest cost batteries come at a cost of about ZAR 2500 per kWhr of stored electrical energy, or ZAR 5000 for a $1 \mathrm{kWh}$ capacity system. Then a DC to AC upconverter is required, at a cost of approximately ZAR 1500 per kWhr, according to our survey. Typical calculations for using the average solar supply values in South Africa, as discussed in Section 1, and assuming a total lifespan of the system over ten years, gives a total cost of ZAR 14 per kWhr over a ten-year capital outlay period.

The estimated savings associated with the utilisation of thermal energy to electricity conversion in South Africa are projected in Table 3 for various ratios of replacing Eskom grid electricity supply. The derived amounts total about ZAR 10000 per annum for the first year, and much higher amounts if anticipated escalation costs are considered in subsequent years. Analysis shows that, on average, a household consuming about $1000 \mathrm{kWh}$ per month, and augmenting grid electricity supply with a $75 \%$ grid replacing TE conversion system, can fully recover its capital outlay within 1.5 years. After this, the household will have a continuous saving of about $80 \%$ of its monthly electricity bill for up to 20 years.

\section{Conclusions}

The following conclusions were derived from this study

- Solar incident thermal energy in the infrared region offers substantial amounts of energy that can be extracted into so-called 'thermal absorbers' on roof tops (or elsewhere) in South Africa.

- A variety of Seebeck p-n cell converters are internationally available with conversion efficiencies of up to $80 \%$. They remain very expensive - of the order of ZAR 1000 per Watt.

- In this study, low-cost Peltier conversion cells that are normally used in Peltier cooling systems in South Africa, and freely available here, have been implemented to provide suitable large-scale thermal to electricity conversion at a first determined conversion efficiency of about $5 \%$.

- Notably, a special electronic charge extraction and control system was developed that increased the efficiency of thermal energy-toelectricity (TE) conversion systems by about $26 \%$ as compared to direct-coupled systems. The energy generated by one cell is about $2 \mathrm{~W}$. 


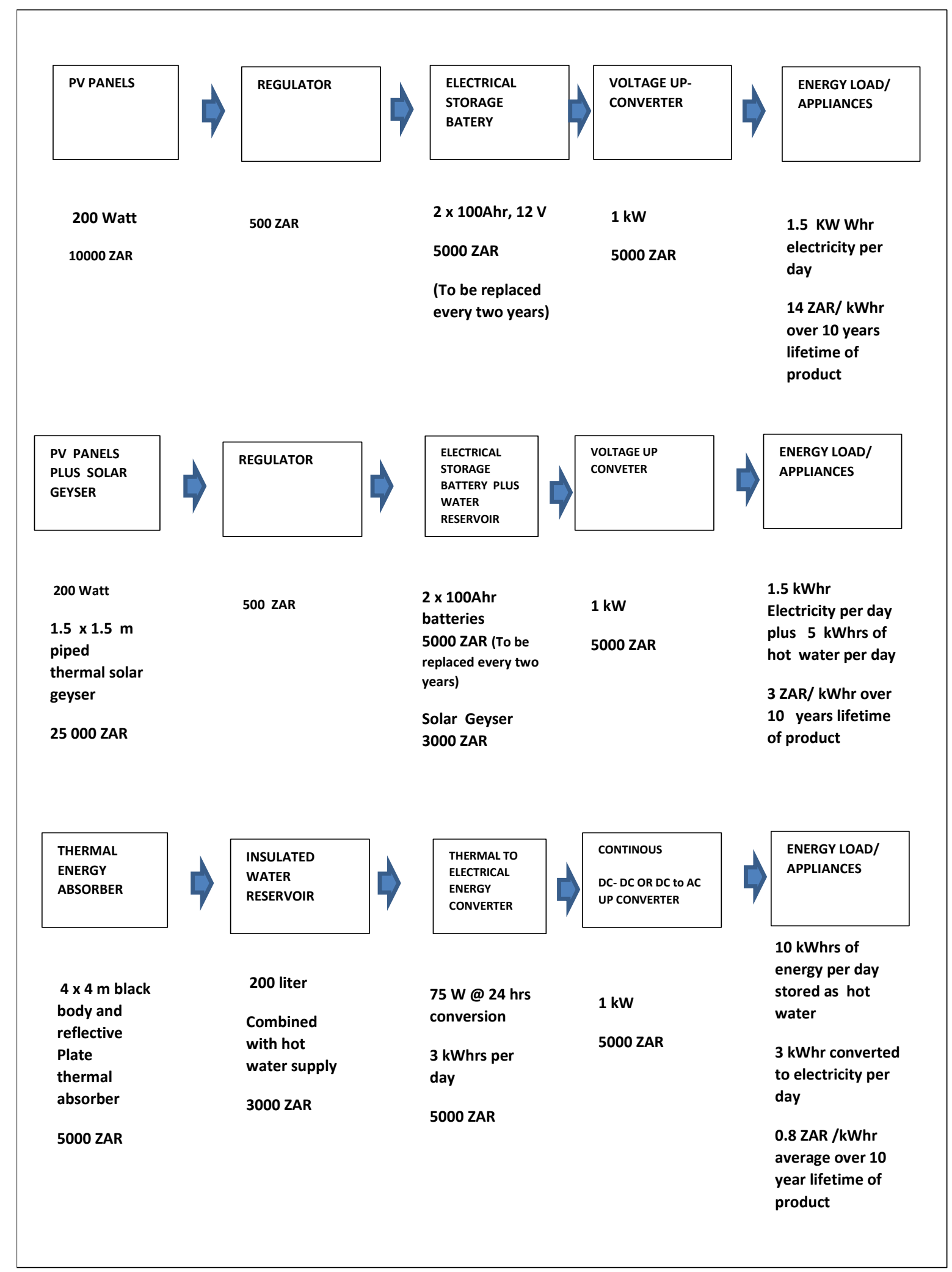

Figure 13: Schematic presentation of the estimated cost aspects over a ten-year lifetime for (top) $1.5 \mathrm{kWh}$ per day capacity conventional PV power supply system;

(centre) $6.5 \mathrm{kWh}$ per day PV solar geyser combination; and (bottom) $10 \mathrm{kWh}$ per day integrated thermal-to-electrical energy conversion system that uses water as an energy storage medium. 
Table 3: Projected costs (in ZAR) for thermal-to-electrical energy conversion technology in a South African household consuming $1000 \mathrm{kWh}$ per month

\begin{tabular}{cccccc}
\hline $\begin{array}{c}\text { Percentage replace- } \\
\text { ment of grid electricity }\end{array}$ & $0 \%$ & $25 \%$ & $50 \%$ & $75 \%$ & $100 \%$ \\
1 & 1150 & 947.36 & 659.86 & 372.36 & 84.86 \\
2 & 2300 & 1894.72 & 1319.72 & 744.72 & 169.72 \\
3 & 3450 & 2842.08 & 1979.58 & 1117.08 & 254.58 \\
4 & 4600 & 3789.44 & 2639.44 & 1489.44 & 339.44 \\
5 & 5750 & 4736.8 & 3299.3 & 1861.8 & 424.3 \\
6 & 6900 & 5684.16 & 3959.16 & 2234.16 & 509.16 \\
7 & 8050 & 6631.52 & 4619.02 & 2606.52 & 594.02 \\
8 & 9200 & 7578.88 & 5278.88 & 2978.88 & 678.88 \\
9 & 10350 & 8526.24 & 5938.74 & 3351.24 & 763.74 \\
10 & 11500 & 9473.6 & 6598.6 & 3723.6 & 848.6 \\
11 & 12650 & 10420.96 & 7258.46 & 4095.96 & 933.46 \\
12 & 13800 & 11368.32 & 7918.32 & 4468.32 & 1018.32 \\
\hline
\end{tabular}

- The cost of the TE conversion systems as developed in this study compares extremely favourably with those associated with current PV energy conversion systems, especially if they are combined with conventional solar waterheating systems. Black body thermal absorbers are a particularly viable source of energy in South Africa, both for water-heating purposes and as a generator of electricity through Seebeck TE converters. Combining the $30 \mathrm{~W}$ capacity system with a black body and reflector plate absorber gave a cost of only ZAR $0.8 / \mathrm{kWh}$ as compared to current PV conversion solar cell systems, with a derived ZAR $3 / \mathrm{kWh}$ for a PV and solar geyser combination over ten years. The cost advantage of the solar geyser-TE combination is attributed to the high collection of thermal energy with low-cost materials, the high density of energy conversion that occurs per small area of one TE cell, and the low- cost storage of energy as hot water in a conventional geyser, and also the possibility of converting energy on a continuous basis with the TE conversion system.

- The current prototype systems can be suitably upscaled to make South African households completely independent of grid electricity supply. The prototype systems developed are suitable for coupling to large-area, low-cost rooftop thermal energy absorbers, sidewall hot sunfacing absorbers, and hot paving absorbers. They could provide energy to power supply demands such as lighting and information and communication equipment. Each of these topics will be within the scope of further research, with the immediate goal being to further im- prove energy conversion efficiency, by developing and optimising the electronic interfacing module with the thermal cells.

\section{Acknowledgments}

Thanks to the Department of Electrical and Mining Engineering in the College of Science Engineering and Technology at the University of South Africa for their financial assistance and support in conducting the research, particularly through their Innovation Support Program of 2016 to 2018. The financial assistance by the National Research Foundation, through its respective THRIP Grant TP1208106781 and Rated Researcher Incentive Funding by the National Research Foundation Rated Researcher Incentive Grant IFR2011033100025, is gratefully acknowledged. The Tshwane University of Technology is thanked for providing laboratory space and equipment and supporting the early stages of this research. $\mathrm{Mr}$ Keven Jalet from L'Ecole Nationale Supérieure de l'Electronique et de Ses Applications in France, who visited CSET Unisa on an internship during 2019, is thanked for constructing and testing the larger TE conversion system.

\section{Intellectual Property Protections}

The content of this article forms the subject of RSA Patent 2016/05297, RSA Patent 2009/03072, RSA Patent 2009/3071, PCT Patent Application WO/2018/09, PCT Patent Application WO/2017/008090, PCT Patent Application PCT/ZA2016/050021.0065, PCT Patent Application PCT/ZA2017/ 050084, and Provisional SA Patents 2012/1508 and 2016/07673 (Snyman, 2012-2018). The intellectual property emanating from the study belongs to the University of South Africa and the Tshwane University of Technology. Copyright protection is also valid on some of the logos used in the article. Blueprints are available of all systems drawings and circuitry drawings from the authors of the article. The intention is to make this technology available to the broader public and business sector of South Africa through appropriate licensing and 
local business creation actions, while a small portion of any profit generated will be channelled back to UNISA to promote further research and development actions. Potential investors and collaborators are welcome to contact the Department of Technology Transfer and Commercialisation office at UNISA.

\section{Author contributions}

This project was completed as an addition to a Masters Degree in Technologiae at College for Science Engineering at the Johannesburg campus of the University of South
Africa. L. Snyman oversaw the project and was primarily responsible for realising the larger conversion system, as well as analysing the economic viability analyses for this study. G. Maeko was responsible for the characterisation of the smaller and initial thermoelectric cells and also the initial electronic interfacing system with the cells, in earlier work at the Tshwane University of Technology under the supervision of Professor Snyman.

\section{References}

Boukai, A.I. 2008, Thermo-electric properties of Bismuth and Silicon nanowires, Thesis, California Institute of Technology, as available at https://thesis.library.caltech.edu/217/ (accessed on 10 July 2019)

Cengel, Y.A., 2016. Heat Transfer: Practical Approach. 2nd edition. Academia.edu, Oxford, England (available at https://www.academia.edu/ (accessed 5 December, 2021)

Chen, G. and Hayward, E. 2008. Nanotech advance heralds a new era in heating, cooling, and power generation. MIT News. Available at http://news.mit.edu/2008/thermoelectric-0320 (accessed on 10 July 2019)

Christophe, W. and André, M. 2016. Les échangeurs de chaleur. Encyclopédie de l'énergie: Article No. 55. Available at: http://www.google.co.za/url?sa=t\&source=web\&ct=j\&url=http://encyclopedie-energie.org/sites/default/files/fichiers_joints/arcticles/art055_Weber-Christopher_Magnificat-Andre_echangeurschaleur_0.pdf\&ved=0ahUKEwi41LeypMDYAhXqKcAKHVDUDIcQFggyMAA\&usg=AOvVaw0Omf_NFYemXhnjpVoilnSk (accessed on 1 August 2017).

Cleveland, C. and Morris, C., ScienceDirect. 2019. Spectral irradiance. Available from: https://www.sciencedirect.com/topics/engineering/spectral-irradiance, (accessed on 10 July 2019).

Communica Pty Ltd. S.A., 53 Landmarks Avenue, Samrand, Centurion, South Africa.

Via Thermodynamic Electronics Jiangxi Corp. Ltd., Nanchang, China. Available at https://thermonamic.en.alibaba.com/(accessed on 1 August 2017)

D.M. Rowe, CRC Handbook of Thermoelectrics. 1995. Edited by Boca Raton: CRC Press.

Day Counter Inc. Engineering Services. 2019. Boost Switching Converter Design Equations. Available at https://daycounter.com/LabBook/BoostConverter/Boost-Converter-Equations.phtml, (accessed on 10 July 2019)

Encyclopedia Britannica. 2019. Thermoelectricity. Available at https://www.britannica.com/science/thermoelectricity (accessed on 10 July 2019)

Eskom Residential Appliance Calculator. 2018. Available at: http://eskom-idm-residential-toolswebapp.fogg.za.com/web/\#/ (accessed on 15 July 2019.

Eskom (2020) Tariffs \& Charges Booklet 2019/2020 p.25. Available at: http://www.eskom.co.za/CustomerCare/TariffsAndCharges/Documents/2019_20\%20Tari ff\%20Book\%20\%281\%20April\%202019\%20rev\%2001\%29.pdf [Accessed 20 April 2019]

Lienhard, J. IV, and Lienhard, J. V., 2011. A heat transfer textbook. 4th edition. Cambridge: Cambridge University Press

Mahan, GD. 2016. Introduction to thermo-electrics: APL Materials: Vol 4, No 10 -, as available at https://aip.scitation.org/doi/full/10.1063/1.4954055, (accessed on 10 July 2019)

Mohan, N, Tore M., Underland, Robbins, R.P. 2003. Power Electronics: Converters, Applications, and Design, 3rd ed., Hoboken, N.J.: J. Wiley \&Sons, Inc.

Mvili-Gampio, S and Snyman, L.W., 2018, Developing a small photovoltaic power supply system with adaptive technologies for rural Africa: Design, cost and efficiency analyses, Journal of Energy in Southern Africa, 29 (4), 60-68

One Energy Company. 2018. Available at: http://www.oneenergy.co.za/products.asp?P_ID=150\&type=2 (accessed on 15 July 2019)

Pay As You Go SOLAR. 2019. Solar irradiation in South Africa and solar water heating performance. Available at https://www.payasyougosolar.co.za/solar-irradiation-in-south-africa-and-solar-water-heating-performance/ (accessed on 10 July 2019)

Saha, S.K., Tiwari, M., Sundén, B., Wu, Z. 2016. Advances in heat transfer enhancement. Basel: Springer International:4.

Schreyer, C.D.R., 2011. Simulation of energy use in residential water heating systems. Master of Applied Science thesis, Department of Mechanical Engineering, University of Victoria:7.

Snyder, G.J. 2008. Small Thermoelectric Generators. The Electrochemical Society Interface, Fall 2008.

Snyder, G. J. and Toberer, E. S. 2008, Nature Materials 7, 105.

Snyder, G. J. 2008. Thermoelectric Energy Harvesting. In Energy Harvesting Technologies, edited by S. Priya. Springer Nature Switzerland AG., pp 325-336 ( Available at https://link.springer.com/book/10.1007/978-0-387-76464-1, accessed 5 December, 2021)

Snyder, G. J. 2008. Thermoelectric Power Generation: Efficiency and Compatibility. In Thermoelectrics Handbook Macro to Nano, edited by D. M. Rowe. 
Snyman L.W. 2008. Self-sustainable solar and thermo-electric supply system for domestic households. SA Patent Journal 2009/03072. Tshwane University of technology.

Snyman, LW., 2008. Smart controller for a household solar energy backup system. Patent 2008/567745, RSA Patent Journal, of May 2008. Granted: SA (2009/3071), Tshwane University of technology.

Snyman, LW., 2012. Low-pressure and high-pressure thermal collection system for South Africa households, SA priority patent application 2012/1508, filed at SA CIPRO. Tshwane University of technology.

Snyman L.W. 2015. Thermal Energy Extractor System (Dual thermal cycle. Solar Power System) Provisional SA Patent 2016/07673, University of South Africa.

Snyman, LW. 2016. Integrated roof solar thermal energy collector. RSA Patent Journal, Patent SA 2016/05297. The University of South Africa.

Snyman, LW 2017. Thermal energy to electrical energy extraction system PCT Patent WO/2018/090065, 17-05-2017, H01L 35/30, PCT/ZA2017/050084, University of South Africa.

Snyman L. W. 2017. Electronic controller for household energy control based on timing and tariff data. PCT Patent, WIPO PATENTSCOPE WO/2017/008090, PCT/ZA2016/050021. The University of South Africa. As available at https://patentscope.wipo.int/search/en/result.jsf?_vid=P12-JXXEAB-90812 (accessed on 10 July 2019).

Sustainable. Co.Za 2019 On-line Eco- Store, as available at https://www.sustainable.co.za/solar-power/solar-panels.html (accessed on 10 July 2019).

Twite, M.F., Snyman L.W., De Koker, J; Yusuff, D. 2019. Development of a large-area, the low-cost solar water-heating system for South Africa with a high thermal energy collection capacity. Journal of Energy in Southern Africa 30 (1), 49-59, ISSN 1021-447X printed version, ISSN 2413-3051 online version, DOI: http://dx.doi.org/10.17159/24133051/2019/v30i1a5226.

SOLARGIS. 2019.Solar resource maps of South Africa. As available at https://solargis.com/maps-and-gis-data/download/south-africa, (accessed on 10 July 2019)

Sze, SM, Li,Y, Kwok, K, Ng, 2021, Photodetectors and Solar Cells, Physics of Semiconductor Devices, Fourth Edition, John Wiley and Sons Inc., New York, pp 755 - 815

Thermodynamic Electronics Jiangxi Corp. Ltd., Nanchang, China. 2017. Available at https://thermonamic.en.alibaba.com/(accessed on 1 August 2017)

Tobaly, P. 2002. Échangeurs de chaleur. Licence professionnelle thesis, IUT of St Denis, (accessed at https://www.academia.edu/32165903/Echangeurs_de_chaleur, 5 December 2021 